\title{
SPRAY DRIED AQUEOUS EXTRACT OF LEMONGRASS (Cymbopogon citratus) EXHIBITS IN VITRO AND IN VIVO ANTI HYPERGLYCEMIC ACTIVITIES
}

\section{AKTIVITAS IN VITRO DAN IN VIVO ANTI HIPERGLISEMIA DARI EKSTRAK AIR SERAI (Cymbopogon citratus) YANG DIKERINGKAN DENGAN METODE SPRAY-DRYING}

\author{
Maria Dewi Puspitasari Tirtaningtyas Gunawan-Puteri ${ }^{1 *)}$, Felicia Rustandi ${ }^{1}$, Phebe Hendra ${ }^{2}$
}

${ }^{1}$ Department of Food Technology, Faculty of Life Sciences and Technology, Swiss German University, The Prominence Tower, Jl. Jalur Sutera Barat Kav. 15, Alam Sutera, Tangerang 15143, Indonesia

${ }^{2}$ Faculty of Pharmacy, Universitas Sanata Dharma, Campus 3 Paingan, Maguwoharjo, Depok, Sleman, Yogyakarta, 55282, Indonesia

Received August 12, 2018; Accepted October 1, 2018

\begin{abstract}
Lemongrass was found to be a promising herb for anti-hyperglycemia treatment due to its activities to inhibit alpha glucosidase and alpha amylase in vitro activities and ability to improve blood glucose profile. Lemongrass potency through its anti-hyperglycemic ingredients requires evaluation of the functional stability during processing. In this study, the in vitro anti-hyperglycemic activities of spraydried aqueous extract of lemongrass were determined by its inhibitory activity against rat intestinal glucosidase enzymatic hydrolysis of sucrose. In vivo activity was observed based on its ability to prevent blood glucose elevation in oral glucose, sucrose and maltose tolerance tests (OGTT, OSTT and OMTT). The in vitro evaluation showed that aqueous extraction, which involved stirring at $70{ }^{\circ} \mathrm{C}$ for $40 \mathrm{~min}$, successfully increased the glucosidase inhibitory activity of lemongrass extract, while spray drying with inlet $130{ }^{\circ} \mathrm{C}$ had no significant impact to the activity tested in vitro. Spray-dried lemongrass powder was found to be effective for lowering blood glucose level in OGTT, OSTT and OMTT. This study provides support for further development of lemongrass extracts as functional ingredients for hyperglycemia treatment.
\end{abstract}

Keywords: anti hyperglycemia, aqueous extract, lemongrass, spray-dried powder

\section{ABSTRAK}

Serai diketahui memiliki aktivitas in vitro untuk menghambat enzim alfa glukosidase dan alfa amilase dan aktivitas in vivo untuk memperbaiki profil gula darah. Potensi serai untuk dikembangkan sebagai bahan baku fungsional dengan aktivitas anti hiperglisemia perlu dikaji dalam kaitannya dengan stabilitas aktivitas fungsionalnya. Pada penelitian ini, ekstrak air serai yang dikeringkan dengan metode spray-drying dikaji aktivitas in vitronya untuk menghambat hidrolisis enzimatis sukrosa oleh enzim glukosidase yang berasal dari usus tikus serta aktivitas in vivonya untuk menghambat kenaikan gula darah mencit setelah uji toleransi oral glukosa, sukrosa, dan maltosa (OGTT, OSTT and OMTT). Ekstraksi air yang dilakukan dengan teknik maserasi dan pengadukan selama 40 menit pada suhu $70{ }^{\circ} \mathrm{C}$, meningkatkan aktivitas in vitro secara signifikan sedangkan pengeringan dengan metode spray drying pada suhu inlet $130{ }^{\circ} \mathrm{C}$ tidak memiliki dampak signifikan terhadap aktivitas in vitro. Bubuk yang dihasilkan dari pengeringan tersebut menurunkan tingkat gula darah secara efektif pada pengujian OGTT, OSTT and OMTT. Hasil penelitian ini diharapkan dapat mendukung pengembangan serai sebagai bahan baku fungsional untuk mengatasi hiperglisemia.

Kata kunci: anti hiperglisemia, ekstrak air, serai, bubuk spray-dry

*Corresponding author: Maria Dewi Puspitasari Tirtaningtyas Gunawan-Puteri

Email: maria.gunawanputeri@sgu.ac.id 


\section{INTRODUCTION}

Lemongrass potencies for diabetic treatment have been reviewed in previous studies (Shah et al., 2011; Geetha and Geetha, 2014), showing 125$500 \mathrm{mg} / \mathrm{kg}$ daily oral dosing of aqueous extract from fresh leaves could lower fasting plasma glucose in male Wistar rats after 42 days of treatment (Adeneye and Agbaje, 2007), though evaluation of its immediate impact to blood glucose has not yet been done. Lemongrass also recently had been extracted in several solvents and evaluated for its in vitro alpha glucosidase inhibitory activities (Santoso et al., 2016; Gunawan-Puteri et al., 2017), resulting in the finding of lemongrass extracted in methanol and ethyl acetate having more than 50\% inhibition activity against sucrase at $0.02 \mathrm{mg} / \mathrm{ml}$ (Santoso et al., 2016). Aqueous extract of lemongrass was optimized and the selected extract was then pulverized using spray drying methods for the production of lemongrass powder for functional food ingredients (Gunawan-Puteri et al., 2017). Spray drying is widely used in the Food industry due to the affordability and effectiveness of the operation and process which are relatively flexible, produce a good quality product and can prolong the shelf life of liquid products as it turns into powder (Munin and Edwards-lévy, 2011). Despite the practicality of powder ingredients, impacts of the extraction optimization and further pulverization to produce spray-dried aqueous extract of Lemongrass on the sucrase inhibition activity in vitro and in vivo have not been observed.

\section{METHODS}

\section{Materials}

Sun-dried lemongrass was collected from Yogyakarta, Indonesia through the herbal supplier CV Sekar Utami. Rat intestinal acetone powder as a source of the glucosidase enzyme was acquired from Sigma-Aldrich, Singapore, while glucose kit $\mathrm{C}$-II for glucose measurement was acquired from Wako, Japan. Potassium phosphate buffer $\mathrm{pH} 7.0$ and ethylenediaminetetraacetic acid were acquired from Sinopharm Chemical Reagent Co., Ltd., China, while analytical grade methanol and maltodextrin were acquired from PT Bratachem, Indonesia. Aluminium oxide 60, sucrose (saccharose), maltose and D-(+)-Glucose anhydrous for biochemistry analysis, and other chemical reagents were acquired from Merck Millipore, Germany, unless stated otherwise.

\section{Plant Samples Preparation}

Sun-dried lemongrass was ground using a miller for $90 \mathrm{~s}$ to reduce the size. Maceration extraction methods were used with the ratio 3:5 $(\mathrm{v} / \mathrm{v})$ between dried lemongrass and water. The basic extraction was done for $24 \mathrm{~h}$ in room temperature while the optimized extraction was done for $40 \mathrm{~min}$ at $70{ }^{\circ} \mathrm{C}$ using stirring. Crude extracts were filtered using vacuum filtration and were subsequently concentrated using a rotary evaporator at reduced pressure at $50{ }^{\circ} \mathrm{C}$ and then stored in amber bottle glass at $4{ }^{\circ} \mathrm{C}$ prior to analysis or spray drying until the total soluble solid reached more than $10 \%$. Selected samples underwent a spray drying process using $130{ }^{\circ} \mathrm{C}$ for the inlet temperature. The nozzle number of the spray dry machine was TD7-97 with the spray angle of $65^{\circ}$.

\section{Rat intestinal glucosidase inhibitory activity assay}

Glucosidase inhibitory activity was determined using methods described previously (Gunawan-Puteri and Kawabata, 2010; Ieyama et al., 2011; Arsiningtyas et al., 2014) with slight revision. Rat intestinal acetone powder was coldground and dissolved in $0.1 \mathrm{M}$ potassium phosphate buffer ( $\mathrm{pH}$ 7.0) containing $5 \mathrm{mM}$ ethylenediaminetetraacetic acid and centrifuged at $11,000 \mathrm{rpm}, 4{ }^{\circ} \mathrm{C}$, for $60 \mathrm{~min}$. The inhibitory activity against sucrose hydrolysis was measured by the following procedures. Two test tubes, as sample and control, containing $0.20 \mathrm{ml}$ sucrose solution $(56 \mathrm{mM})$ in potassium phosphate buffer $(0.1 \mathrm{M}, \mathrm{pH} 7.0)$ and two test tubes, containing 0.40 $\mathrm{ml}$ potassium phosphate buffer $(0.1 \mathrm{M}, \mathrm{pH} 7.0)$ as each blank were pre-incubated at $37^{\circ} \mathrm{C}$ for $5 \mathrm{~min}$. The control and control blank were defined as $100 \%$ and $0 \%$ enzyme activity, respectively. The working samples diluted in water $(0.10 \mathrm{ml})$ were added to the sample and sample blank test tubes while $0.10 \mathrm{ml}$ water was added to the control and control blank test tubes. Next, crude rat intestinal sucrase $(0.20 \mathrm{ml})$ was added only to the test tubes containing sucrose solution (sample and control). The reaction was done at $37{ }^{\circ} \mathrm{C}$ for $20 \mathrm{~min}$ and stopped by adding Tris- $\mathrm{HCl}$ buffer $(2 \mathrm{M}, \mathrm{pH} 6.3$, $0.75 \mathrm{ml}$ ).

The reaction mixtures were then passed through a short column of Aluminium oxide 60 $(1.5 \mathrm{~g}, 500 \times 5 \mathrm{~mm})$ for removing phenolics, which may interfere with the following glucose quantification. Each mixture $(50 \mu \mathrm{l})$ was placed into a 96-well microplate and added with $200 \mu \mathrm{l}$ 
glucose kit and incubated at $37{ }^{\circ} \mathrm{C}$ for $15 \mathrm{~min}$. The absorbance (Abs) was measured using a UV-Vis spectrophotometer at $492 \mathrm{~nm}$ wavelength.

Inhibitory activity was calculated by the following equation:

$$
\text { Inhibitory activity }(\%)=\frac{\left(A_{b 5} C-A_{b s} C b\right)-\left(A b s s-A_{b a s b}\right)}{\left(A_{b s} C-A_{b b s} C b\right)} \times 100 \%
$$

with Abs = Absorbance, $[\mathrm{c}]=$ control, $[\mathrm{cb}]=$ control blank, $[\mathrm{s}]=$ sample, $[\mathrm{sb}]=$ sample blank

The experiments were done in triplicate for each concentration and the resulting sucrase inhibitory activity was plotted in the curve against concentration to derive the linear regression mathematical formula. Data were presented as $\mathrm{IC}_{50}$, which was defined as lemongrass concentration that inhibits $50 \%$ of sucrose hydrolysis into glucose and fructose in the presence of crude extract of rat intestinal acetone powder.

\section{Test animals and housing}

All experiments were performed on adult male Swiss mice $(20$ - $30 \mathrm{~g})$ obtained from the Imono Laboratory, Sanata Dharma University, Indonesia. The animals were maintained under standard laboratory condition. They were housed in standard cages at temperature $22 \pm 2{ }^{\circ} \mathrm{C}$ and 12:12 h light dark cycle. Standard pelleted diet and water were given ad libitum. All procedures described were reviewed and approved with approval number KE/KF/0618/EC/2017 by the Health and Medical Research Ethics Committee Faculty of Medicine Universitas Gadjah Mada Dr. Sardjito General Hospital, Yogyakarta Indonesia.

\section{Sugar tolerance test}

Anti-hyperglycemic activity of spray-dried aqueous extract of lemongrass was tested using carbohydrate loads in mice. Overnight fasted mice were used to perform oral glucose tolerance test (OGTT), oral sucrose tolerance test (OSTT) and oral maltose tolerance test (OMTT). Male Swiss mice were divided into fifteen groups $(n=5)$ randomly (negative control, sugar [glucose/sucrose] control, positive control and dose groups).

For glucose control Group I received $2 \mathrm{~g} / \mathrm{kg}$ BW glucose solution orally and Group II were given acarbose $0.08 \mathrm{~g} / \mathrm{kg} \mathrm{BW}$ for the positive control. Group III-V (treated-glucose groups) received $4.33 ; 6.67 ; 10 \mathrm{~g} / \mathrm{kg} \mathrm{BW}$ of spray-dried aqueous extract of Lemongrass respectively. After $30 \mathrm{~min}$ of treatment, glucose solution was administered to all mice of Group II-V at $2 \mathrm{~g} / \mathrm{kg}$ BW (James et al., 2009; Pattanayak et al., 2009; Rathod et al., 2011; Ali et al., 2013).

Group VI (sucrose control) received $4 \mathrm{~g} / \mathrm{kg}$ BW sucrose solution orally. Group VII (positive control) was treated with acarbose $0.08 \mathrm{~g} / \mathrm{kg} \mathrm{BW}$. Group VIII-X (treated-sucrose groups) received $4.33 ; 6.67 ; 10 \mathrm{~g} / \mathrm{kg} \mathrm{BW}$ of spray-dried aqueous extract of Lemongrass respectively. After $30 \mathrm{~min}$ of treatment, the animals were administered sucrose solution $4 \mathrm{~g} / \mathrm{kg}$ BW (Ali et al., 2013; Yusoff et al., 2015).

Group XI as maltose control received $3 \mathrm{~g} / \mathrm{kg}$ BW orally. Group XII (positive control) was treated with acarbose $0.08 \mathrm{~g} / \mathrm{kg} \mathrm{BW}$. Group XIII$\mathrm{XV}$ (treated-maltose groups) received $4.33 ; 6.67$; $10 \mathrm{~g} / \mathrm{kg} \mathrm{BW}$ of spray-dried aqueous extract of Lemongrass, respectively. After $30 \mathrm{~min}$ of treatment, the animals were administered maltose solution $3 \mathrm{~g} / \mathrm{kg}$ BW (Wongnawa et al., 2014; Bae et al., 2015).

Blood collected from the tail vein of the mice and blood glucose levels were measured at 0 , 15, 30, 60, 90 and 120 min using a glucometer (GlucoDr, All Medicus Co. Ltd) (Yeo et al., 2011; Wongnawa et al., 2014). Area under the blood glucose-time curve up to the last sampled timepoint (AUC) was calculated using the trapezoid method formula (Eseyin et al., 2010; Jo et al., 2011; Yusoff et al., 2015).

\section{Statistical analysis}

Results are expressed as mean \pm standard deviation (SD). Data were analyzed using KruskalWallis analysis of variance followed by post-hoc Mann-Whitney tests using SPSS 22. A p-value $<0.05$ was considered statistically significant.

AUC (Area under the curve) was estimated by the trapezoid method formula (Hendra et al., 2017), as below:

$$
\mathrm{AUC}=\left(\frac{C 1-C 0}{2} \times \mathrm{t}_{1}-\mathrm{t}_{0}\right)+\left(\frac{C 2-C 1}{2} \times \mathrm{t}_{2}-\mathrm{t}_{1}\right)+\ldots+\left(\frac{C n-C n-1}{2} \times \mathrm{t}_{\mathrm{n}}-\mathrm{t}_{\mathrm{n}-1}\right)
$$

with $\mathrm{T}=$ time, $\mathrm{C}=$ concentration of glucose . 
Table I. The Glucosidase Inhibitory Activity of Lemongrass Extract and Powder

\begin{tabular}{llc}
\hline \multicolumn{1}{c}{ Samples } & \multicolumn{1}{c}{ Treatments } & $\begin{array}{c}\text { Glucosidase } \\
\mathrm{IC}_{50}(\mathrm{mg} / \mathrm{ml})\end{array}$ \\
\hline LG Extract 1 & Extraction: Maceration, room temperature, 24 h & 132.89 \\
LG Extract 2 & Extraction: Maceration, stirring, 70 ${ }^{\circ} \mathrm{C}, 40 \mathrm{~min}$ & 14.46 \\
LG Powder & Extraction: Maceration, stirring, 70 ${ }^{\circ} \mathrm{C}, 40 \mathrm{~min}$; Spray drying: & 18.22 \\
& Inlet $130{ }^{\circ} \mathrm{C}$, spray angle $65^{\circ}$ & \\
\hline
\end{tabular}

Note: Values were presented as $\mathrm{IC}_{50}$, defined as Lemongrass concentration to inhibit $50 \%$ of sucrose hydrolysis reaction in vitro.
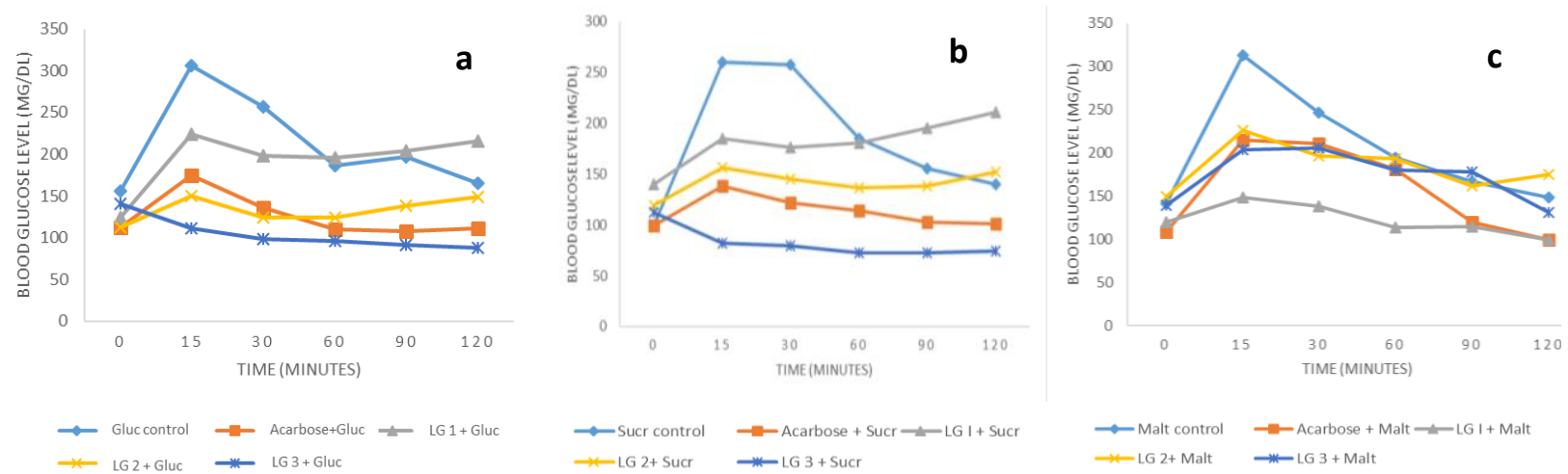

Figure 1. Effects of spray-dried lemongrass powder in oral glucose (a), sucrose (b), and maltose (c) loading test on mice. Values are expressed as mean $(n=5)$. Gluc: glucose, Sucr: Sucrose LG: Spray-dried Lemongrass powder.

\section{RESULT AND DISCUSSION}

Our results showed that the optimized extraction method using water solvent at $70^{\circ} \mathrm{C}$ increased the glucosidase inhibitory activity of the lemongrass extract despite the very short extraction time (40 min) compared to the basic extraction at room temperature for $24 \mathrm{~h}$ (Table I). While further study is required to show the active compound responsible for the sucrase inhibitory activity, previous study showed positive correlation of phenolic content and alpha glucosidase inhibitory activity of Indonesian medicinal plants tested, including lemongrass (Santoso et al., 2016). Aqueous extract of lemongrass is known to contain phenolics, such as caffeic acid, chlorogenic acid, catechol, elimicin, and hydroquinone (Shah et al., 2011), and some of the aforementioned compounds, such as caffeic and chlorogenic acids, were already known for its alpha glucosidase inhibitory activity in vitro (Oboh et al., 2015). Previous observations of the effect of extraction solvents, temperature and time on the total phenolic content in Salvia officinalis L. showed that higher temperature in combination with polar solvent increased phenolic solubility and diffusion coefficient. Best extraction conditions according to the higher total phenolic content were acquired using 30\% ethanolic extraction at $60{ }^{\circ} \mathrm{C}$ for $30 \mathrm{~min}$, followed by aqueous extraction at $60{ }^{\circ} \mathrm{C}$ for 90 min and water extraction at higher temperature was shown as the most desirable extraction method to acquire more caffeic acid in other plants (Dent et al., 2012).

Sudden heat exposure in the spray drying process was seen to reduce $26.09 \%$ of the sucrase inhibitory activity. Previous study shown that the addition of both maltodextrin and combination of maltodextrin and Arabic gum seemed to reduce the inhibitory activity even more (Gunawan-Puteri et al., 2017). Encapsulation is a common practice in pulverization using spray drying due to its ability to protect products from heat and decrease sticking possibility inside the spray dryer (Nogueira et al., 2014). Maltodextrin of DE 20-21 has been found as the best encapsulation agent for anthocyanin, while the combination of maltodextrin and Arabic gum (3:2) was shown to be the best encapsulating agent of polyanilines (Munin and Edwards-Levy, 2011). However, both encapsulating agents are a polysaccharide carbohydrate and though it may protect the active compound in the Lemongrass extract, it may also hydrolyze by heat in spray drying process or enzymatic treatment in sucrase inhibitory activity analysis contributing to the higher content of glucose in the end of analysis (Parikh et al., 2014). 
Table II. The Area Under Curve in Oral Sugar Loading Test after Administration Acarbose and Spray-Dried Lemongrass Powder on Mice

\begin{tabular}{cccc}
\hline \multirow{2}{*}{ Treatment* $^{*}$} & \multicolumn{2}{c}{ Area Under Curve (mg.min/dl) } \\
\cline { 2 - 4 } OGTT & OSTT & OMTT \\
\hline Sugar control & $25530 \pm 1924^{\mathrm{a}}$ & $22739 \pm 2343^{\mathrm{a}}$ & $24349 \pm 2878$ \\
Acarbose 0.08 g/kg BW & $14624 \pm 2001^{\mathrm{b}}$ & $13568 \pm 1270^{\mathrm{c}}$ & $19303 \pm 1812$ \\
LG 4.33 g/kg BW & $23996 \pm 745^{\mathrm{a}}$ & $22191 \pm 1021^{\mathrm{a}}$ & $14472 \pm 3205^{\mathrm{d}}$ \\
LG 6.67 g/kg BW & $16034 \pm 2045^{\mathrm{b}}$ & $17037 \pm 1875^{\mathrm{c}}$ & $21817 \pm 4248$ \\
& & & \\
LG 10 g/kg BW & $11888 \pm 1974^{\mathrm{b}}$ & $9355 \pm 1609^{\mathrm{a}, \mathrm{c}}$ & $21421 \pm 3364$ \\
\hline
\end{tabular}

*Treatments were co-administered orally and respectively with glucose (2 g/kg BW) in OGTT test, sucrose $(4 \mathrm{~g} / \mathrm{kg} \mathrm{BW})$ in OSTT test and maltose $(3 \mathrm{~g} / \mathrm{kg} \mathrm{BW})$ in OMTT. Values are expressed as mean $\pm \mathrm{SD}$ of five animals in each group; a: $p<0.05$ vs acarbose; b: $p<0.05$ vs glucose; $\mathrm{c}: p<0.05$ vs sucrose; $\mathrm{d}: p<0.05$ vs maltose. LG: Spray-dried Lemongrass powder.

In the in vivo study, sugar tolerance tests in mice were employed to observe the antihyperglycemic activity of spray-dried lemongrass powder. The blood glucose levels increased 15 min after administration of glucose (2 g/kg BW), consistent with previous results (Mustaffa et al., 2014) (Figure 1A). Similar patterns were observed in sucrose loading $(4 \mathrm{~g} / \mathrm{kg} \mathrm{BW})$ and maltose loading ( $3 \mathrm{~g} / \mathrm{kg} \mathrm{BW}$ ) (Figure 1B and 1C).

Administration of lemongrass extract for 30 days caused a steady decrease in blood glucose levels in normal rats (Ademuyiwa et al., 2015). However, no sugar tolerance test has been reported yet. Spray-dried lemongrass powder with oral dose of $6.67 \mathrm{~g} / \mathrm{kg} \mathrm{BW}$ was found to be effective in lowering blood glucose level in glucose and sucrose tolerance tests, while a significant decrease in AUC at dose $4.33 \mathrm{~g} / \mathrm{kg} \mathrm{BW}$ was observed in the maltose tolerance test (Table II). This finding suggested that spray-dried lemongrass powder probably exerted its antidiabetic effect via suppressing postprandial hyperglycemia. The present study confirmed the result of our previous study that shown lemongrass had an inhibition activity against sucrase (Nivetha et al., 2016; Santoso et al., 2016; Gunawan-Puteri et al., 2017). Glucose derived from the diet and body synthesized needs transporters (SGLT, GLUT) to be transported into the bloodstream and cells (Wright et al., 2003), and before glucose is transported to the cells and stored for a source of energy, glucose exists in the bloodstream (Aronoff et al., 2004). There are several mechanisms to decrease the amount of glucose in the bloodstream, such as inhibition of glucose transporter and acceleration of the number of glucose transporters (Wood and Trayhurn, 2003). The effect of spray- dried lemongrass powder in prevention of blood glucose rise in OGTT test indicates the possibility that lemongrass might possess other antihyperglycemic activities than sucrase inhibitory activity.

The oral dose of $10.00 \mathrm{~g} / \mathrm{kg} \mathrm{BW}$ seemed to lower blood glucose to levels that are lower than acarbose treatment (Table II). Acarbose is a commercial anti-hyperglycemic medicine that has been used for more than 20 years to control hyperglycemia (Rosak and Mertes, 2012) and its ability to reduce hyperglycemia in sucrose tolerance tests has been proved (Ali et al., 2013). Nonetheless, the effect caused by the treatment of oral dose of $10.00 \mathrm{~g} / \mathrm{kg} \mathrm{BW}$ lead to the conclusion that the dose might not be suitable to be further observed in humans since it caused abrupt blood glucose lowering impact that may lead into hypoglycemia and subsequent drawbacks.

\section{CONCLUSION}

This study found that the aqueous extraction method, which involved stirring at $70{ }^{\circ} \mathrm{C}$ for 40 min successfully increased the sucrase inhibitory activity of lemongrass extract, while spray drying with inlet $130{ }^{\circ} \mathrm{C}$ did not have significant impact. The spray-dried lemongrass powder proved to be effective in lowering blood glucose level on OGTT, OSTT and OMTT.

\section{ACKNOWLEDGEMENT}

This research project was supported by a grant from the Directorate General of Resources for Science, Technology and Higher Education of the Republic of Indonesia with contract number 0789/K4/KM/2018. 


\section{REFERENCES}

Adeneye, A.A. and Agbaje, E.O., 2007. Hypoglycemic and hypolipidemic effects of fresh leaf aqueous extract of Cymbopogon citratus Stapf. in rats. Journal of Ethnopharmacology, 112(3), 440-444.

Ademuyiwa, A. J., Olamide, O. Y. and Oluwatosin, O. O. 2015. The effects of Cymbopogon citratus (Lemongrass) on the blood sugar level, lipid profiles and hormonal profiles of Wistar albino rats. American Journal of Toxicology, 1, 8-18.

Ali, R. B., Atangwho, I. J., Kuar, N., Ahmad, M., Mahmud, R. and Asmawi, M.Z. 2013. In vitro and in vivo effects of standardized extract and fractions of Phaleria macrocarpa fruits pericarp on lead carbohydrate digesting enzymes. BMC Complementary and Alternative Medicine, 13(1), 1-11.

Aronoff, S. L., Berkowitz, K., Shreiner, B. and Want, L. 2004. Glucose metabolism and regulation: beyond insulin and glucagon. Diabetes Spectrum, 17, 183-190.

Arsiningtyas, I. S., Gunawan-Puteri, M. D. P. T., Kato, E. and Kawabata, J. 2014. Identification of $\alpha$-glucosidase inhibitors from the leaves of Pluchea indica (L.) Less., a traditional Indonesian herb: promotion of natural product use. Natural Product Research, 28(17), 1350-1353.

Bae, I.J., Park, S.H., Jung, S.Y., Park. B.H. and Chae, S.W. 2015. Hypoglycemic effects of aqueous persimmon leaf extract in a murine model of diabetes. Molecular Medicine Reports, 12, 2547-2554.

Dent, M., Dragovic-Uzelac, V., Penic, M., Brncic, M., Bosiljkov, T. and Levaj, B. 2012. The effect of extraction solvents, temperature and time on the composition and mass fraction of polyphenols in Dalmatian wild sage (Salvia officinalis L.) extracts. Food Technology Biotechnology, 51(1), 84-91.

Eseyin, O., Ebong, P., Eyong, E., Awofisayo, O. and Agboke, A. 2010. Effects of Telfairia occidentalis on oral glucose tolerance in rats. African Journal of Pharmacy and Pharmacology, 4(6), 368-372.

Geetha, T. S. and Geetha, N. 2014. Phytochemical screening, quantitative analysis of primary and secondary metabolites of Cymbopogon citratus (DC) stapf. leaves from Kodaikanal hills, Tamilnadu. International Journal of PharmTech Research, 6(2), 521-529.

Gunawan-Puteri, M. D. P. T. and Kawabata, J. 2010. Novel $\alpha$-glucosidase inhibitors from
Macaranga tanarius leaves. Food Chemistry, 123(2), 384-389.

Gunawan-Puteri, M. D. P. T., Josopandojo, B. M., Adiyoga, G. H., Kartawiria, I. S. and Widiputri, D.I. 2017. Aqueous extraction optimization of C. citratus for development of food ingredients with alpha glucosidase inhibitory. In Sukmana, I. and Ulvan, A. (Eds). Integrated SciTech: Interdisciplinary Research Approach. Vol. 2, p. 55-61. Indonesia: Research Institute and Community Services University of Lampung.

Hendra, P., Fenty, Andreani, P. R., Pangestuti, M. E. and Julianus, J. 2017. Evaluation of antihyperlipidemic, anti-Inflammatory, and analgesic activities of Eurycoma longifolia in animal models. International Journal of Pharmacy and Pharmaceutical Sciences, 9(3), 166-169.

Ieyama, T., Gunawan-Puteri, M. D. P. T. and Kawabata, J. 2011. $\alpha$-Glucosidase inhibitors from the bulb of Eleutherine americana. Food Chemistry, 128(2), 308-311.

James, D. B., Owolabi, O. A., Elebo, N., Hassan, S. and Odemene, L. 2009. Glucose tolerance test and some biochemical effect of Phyllanthus amarus aqueous extracts on normaglycemic Albino rats. African Journal of Biotechnology, 8(8), 1637-1642.

Jo, S. H., Ha, K. S., Moon, K. S., Lee, O. H., Jang, H. D. and Kwon, Y. I. 2011. In vitro and in vivo anti-hyperglycemic effects of Omija (Schizandra chinensis) fruit. International Journal of Molecular Sciences, 12(2), 13591370.

Munin, A. and Edwards-Levy, F. 2011. Review of Encapsulation of natural polyphenolic compounds; a review. Pharmaceutics, 3(4), 793-829.

Mustaffa, F., Hassan, Z., Yusof, N. A., Razak, K. N. A. and Asmawi, M. Z. 2014. Antidiabetic Mechanism of standardized extract, fraction and subfraction of Cinnamomum iners leaves. International Journal of Pharmaceutical Sciences Review and Research, 26(2), 209214.

Nivetha, G., Vishnupriya, V. and Gayathri, R. 2016. Comparative evaluation of anti-diabetic activity of Lemon Grass oil and Tulasi oil. International Journal of Pharmaceutical Sciences Review and Research, 39(1), 221225. 
Nogueira, R. I., Santiago, M. C. P. de A., Paim, D. R. S. F., Santos, L. F., Carlos, A. L. M., Wilberg V. C., Godoy, R. L. O. and Freitas, S.P. 2014. Aqueous extract of pomegranate peels (Punica granatum) encapsulated by spray drying. Proceeding of the 19th International Drying Symposium 24-27 Aug 2014. Lyon: France.

Oboh, G., Agunloye, O. M., Adefegha, S.A., Akinyemi, A. J., and Ademiluyi, A. O. 2015. Caffeic and chlorogenic acids inhibit key enzymes linked to type 2 diabetes (in vitro): a comparative study. Journal of Basic and Clinical Physiology and Pharmacology, 26(2), 165-170.

Parikh, A., Siddharth, A. and Kirtesh, R. A. 2014. A review on applications of maltodextrin in pharmaceutical industry. International Journal of Pharmacy and Biological Sciences, 4(4), 67-74.

Pattanayak, S., Nayak, S. S., Pand, D. and Shende, V. 2009. Hypoglycemic of Cajanus scarabaeoides in glucose overloaded and streptozotocin-induced diabetic rats. Bangladesh Journal of Pharmacology, 4(2), 131-135.

Rathod, N. R., Chitme, H. R., Irchhaiya, R. and Chandra, R. 2011. Hypoglycemic effect of Calotropis gigantean Linn. leaves and flowers in streptozotocin-induced diabetic rats. Oman Medical Journal, 26(2), 104-108.

Rosak, C. and Mertes, G. 2012. Critical evaluation of the role of acarbose in the treatment of diabetes: patient considerations. Diabetes, Metabolic Syndrome and Obesity, 5, 357367.

Santoso, S., Soedarma, C., Adiyoga, G. H., Gunawan-Puteri, M. D. P. T. and Sutanto, H. 2016. Alpha-glucosidase inhibitory effect of methanolic extracts from Indonesian plants. Proceeding of the 2nd International Conference on Sustainable Global Agriculture and Food 9-11 Aug 2016. Semarang: Indonesia.

Shah, G., Shri, R., Panchal, V., Sharma, N., Singh, B. and Mann, A.S. 2011. Scientific basis for the therapeutic use of Cymbopogon citratus, stapf (Lemon grass). Journal of Advanced Pharmaceutical Technology and Research, 2(1), 3-8.

Wongnawa, M., Tohkayomatee, R., Bumrungwong, N. and Wongnawa. S. 2014. Alpha-glucosidase inhibitory effect and inorganic constituents of Phyllantus amarus Schum. \& Thonn.ash. Songklanakarin Journal of Science and Technology, 36(5), 541-546.

Wood, I. S. and Trayhurn, P. 2003. Glucose transporters (GLUT and SGLT): Expanded families of sugar transport proteins. British Journal of Nutrition, 89, 3-9.

Wright, E. M., Martin, M. G. and Turk, E. 2003. Intestinal Absorption in health and diseasesugars. Best Practice and Research, Clinical Gastroenterology, 17(6), 943-956.

Yeo, J. Y., Ha, T. J., Nam, J. S. and Jung, M. H. 2011. Antidiabetic effects of Vigna nakashimae extract in $\mathrm{db} / \mathrm{db}$ mice. Bioscience, Biotechnology, and Biochemistry, 75(11), 2223-2228.

Yusoff, N. A., Ahmad, M., Hindi, B., Widyawati, T., Yam, M. F., Mahmud, R., Razak, K. N. A., and Asmawi, M. Z. 2015. Aqueous extract of Nypa fruticans Wurmb. vinegar alleviates postprandial hyperglycemia in normoglycemic rats. Nutrients, 7(8), 70127026 . 